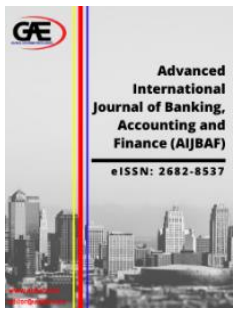

\author{
ADVANCED INTERNATIONAL JOURNAL OF \\ BANKING, ACCOUNTING AND FINANCE \\ (AIJBAF) \\ www.aijbaf.com
}

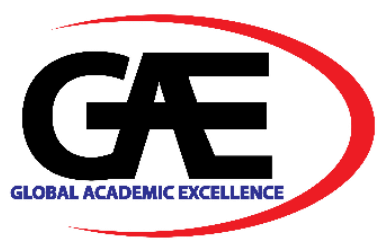

\title{
WHAT DRIVES FINANCIAL DISTRESS FOR PN4 AND PN17 LISTED FIRMS IN MALAYSIA?
}

\author{
Ahmad Harith Ashrofie Hanafi ${ }^{1 *}$, Wan Rozima Mior Ahmed Shahimi ${ }^{2}$ \\ 1 Faculty of Business and Finance, Universiti Tunku Abdul Rahman, Kampar, Malaysia \\ Email: harith@utar.edu.my \\ 2 Faculty of Business and Finance, Universiti Tunku Abdul Rahman, Kampar, Malaysia \\ Email: rozima@utar.edu.my \\ * Corresponding Author
}

\section{Article Info:}

Article history:

Received date: 19.08 .2020

Revised date: 25.08 .2020

Accepted date: 29.08 .2020

Published date: 10.09 .2020

\section{To cite this document:}

Hanafi, A. H., A., \& Shahimi, W. R. M. A. (2020). What Drives Financial Distress for PN4 and PN17 Listed Firms in Malaysia. Advanced International Journal of Banking, Accounting, and Finance, 2 (4), 01-09.

DOI: $10.35631 /$ AIJBAF.24001.

\begin{abstract}
:
Research on financial distress has attracted growing attention in the recent past. Enormous corporate failures in history have pointed to the need for deepened research on financial distress. This study attempts to predict the financial distress of listed firms in the Malaysian Stock Market by using firms' financial ratios. Using Logit Regression Analysis, this study analysed a sample from Malaysian public listed firms from the year 2000 to 2018 to predict the probability of financial distress events. It showed that financial distress such as total assets turnover, earnings before interest and tax to sales, debt ratio, and shareholder's fund to total debt were found to be significant in predicting financial distress. Based on the confusion matrix approach the developed model showed high accuracy in predicting financial distress since it could predict most of the cases within the sample correctly.
\end{abstract}

Keywords:

Bankruptcy, Financial Distress, Financial Ratio

\section{Introduction}

In the late 1980s and early 1990s, Malaysia experienced extraordinary growth until the Asian Financial Crisis struck the nation in 1997. As a result, many Malaysian firms were forced into financial distress status after the stock market fell to almost $54 \%$ during this market turbulence (Khaliq, Altarturi, Thaker, Harun \& Nahar, 2014). Due to this situation, Bursa Malaysia has introduced Practice Note 4 (PN4) on $15^{\text {th }}$ February 2001 to have separate classification specifically for financially distressed firms. The PN4 has been revised to Practice Note 17 
(PN17) on $3^{\text {rd }}$ January 2005. Under this provision, a listed firm that is financially distressed or has failed to meet the minimum capital or equity (less than $25 \%$ of the total paid up capital) is categorised under the PN17 set by Bursa Malaysia. Literally, PN4 firms have worse financial status compared to PN17 firms (Abdullah, 2006).

Tinoco and Wilson (2013) defined financial distress as a condition where a firm fails to generate revenues and hard to meet its debt obligation. It is considered as a last phase prior to bankruptcy. Firms that enter the financial distress status have two possible conditions that contribute to the status which are (1) the cash shortage or (or and) (2) debt overhang. Nevertheless, both conditions are inferentially contributed to an inability for the firms to meet current obligations due to a temporary liquidity insufficiency to meet their financial obligations on schedule.

The future and performance of the firms that are classified under PN4 and PN17 categories remain as going concerns. The inability of investors to carefully predict the probability of financial distress may cause them to hold shares with potential PN4 and PN17 status which may adversely affect their investment portfolio. However, research on predicting financial distress based on PN4 and PN17 firm is still inadequate in Malaysia and the result is still inconclusive (Abdullah \& Ahmad, 2005). Therefore, findings from this research are expected to shed some lights on factors which deemed to be important in determining the probability of financial distress among public listed companies in Malaysia market.

\section{Literature Review}

In this section, this study summarises about the past studies in financial ratios which provide noteworthy evidences that have been researched in the prediction of corporate financial distress. Specifically, few previous studies are divided empirically as below.

\section{Liquidity ratio and Financial Distress}

Liquidity ratio measures the ability of the firm to meet its short-term debt obligations. Theoretically, the higher liquidity ratios, the less likely the firms are to suffer from financial distress. Most researchers reported that the current ratio has negative relationship and is insignificant to the financial distress (e.g. Almansour, 2015; Bunn \& Redwood, 2003; Low, Nor \& Yatim, 2001). The argument is that the high liquidity, firms have lower probability to bankruptcy. Besides that, Low et al. (2001) found that the current ratio was significant in identifying the signs of financial distress but argued that firm with magnanimous cash had no assurance in its ability to repay its liabilities on timely manner. Meanwhile, Platt and Platt (2008) found that greater sales to working capital managed to reduce the risk of financial distress in the U.S, Europe and Asia. In other research, Nair (2018) investigated distress firms of Indian steel sector and found the mean of sales to working capital turnover was negative as an indicator of distress. Oppositely in recent study, Reis (2019) discovered this ratio was not significant in predicting financial distress for manufacturing firms in Portugal. Hence, based on the literature, the testable hypothesis is:

H1: The liquidity ratios could negatively predict financial distress for PN4 and PN17 listed firms in Malaysia. 


\section{Activity Ratio and Financial Distress}

Activity ratio measures the capability of a firm's assets to be converted into cash or sales (Altman \& Narayanan, 1997). A higher activity ratio represents a more efficient of total assets in generating sales, and vice versa. Theoretically, the higher assets turnover, the less likely the firms are to suffer from financial distress. Lakshan and Wijekoon (2013) examined the firms listed on Colombo stock market and formed consistent result with Laitinen (1992) in which assets turnover ratio was not significant in distinguishing between failed firms and non-failed firms. Though, Altman and Narayanan (1997) differently indicated that total assets turnover was useful as a ratio to predict failure. Nonetheless, Restianti and Agustina (2018) pointed out that total assets turnover had no influence and did not have positive impact on financial of distressed firms. Alifiah, Salamudin and Ahmad (2013) and Almansour (2015) emphasized this ratio was among the most useful independent variables to predict the firms that are in financial distress and with negative relationship between these variables. Hence, based on the literature, the testable hypothesis is:

$\mathrm{H} 2$ : The activity ratios could negatively predict financial distress for PN4 and PN17 listed firms in Malaysia

\section{Profitability Ratio and Financial Distress}

Profitability ratio measures the ability of a firm to generate profit relative to its operations. Theoretically, the higher profitability ratio, the less likely the firms are to suffer from financial distress. Tuvadaratragool (2013) investigated the role of financial ratio to adequately signal financial distress in Thailand and confirmed that mean for earnings before interest and tax to sales of profitability for the failed firms was less than the non-failed firms. According to Platt and Platt (2002) and Parker, Peters and Turetsky (2002), the operating profit margin was a significant ratio to predict financial distress firms. Apart from that, many researchers found that the net profit margin was one the most influence ratio of financial distress (e.g. Kim \& Upneja, 2014; Tuckman \& Chang, 1991). As net profit margin decreases, the probability of financial distress increases (Kim \& Upneja, 2014). However, Yuniarti (2012) found that the net profit margin had no effect on the financial distress. Hence, based on the literature, the testable hypothesis is:

H3: The profitability ratios could negatively predict financial distress for PN4 and PN17 listed firms in Malaysia.

\section{Leverage Ratio and Financial Distress}

Leverage ratio measures on how far the firm's assets are financed with debt. Theoretically, the higher profitability ratio, the more likely the firms are to suffer from financial distress. One of the earlier researchers in this field, Baever (1966) and Dambolena and Khoury (1980) confirmed that debt ratio was one of the best predictors of financial distress where it could predict corporate failure a few years prior before the failure. This result was consistent with a study by Abdullah, Zainudin, Ahmad and Md-Rus (2014) which suggested that debt ratio was significant to differentiate between distressed and non-distressed firms for SMEs in Malaysia. Meanwhile, Tinoco and Wilson (2013) and Min and Lee (2008) found that a negative relationship between the firm's financial distresses which indicates the ability to pay interest expenses on outstanding debt would lower the likelihood of financial distress. For other perspective, many studies found that interest coverage ratio was the most important and 
significant in explaining insolvency (e.g. Jackson, Bogonko \& Kimutai, 2018; Mohamed, Ang \& Ahmadu, 2001; Scalzer, Rodrigues, Macedo \& Wanke, 2018). There are also studies that use ratio based on capital structure such as study by Abdullah and Ahmad (2005) which used shareholder's fund to total debt. They found that this variable is positively significant and very useful to predict financial distress. Due to the different direction expected from each variables in predicting financial distress, this study only develop general hypothesis to test the ability of leverage ratios in predicting financial distress. Thus, the testable hypothesis is:

H4: The leverage ratios could predict financial distress for PN4 and PN17 listed firms in Malaysia.

\section{Methodology}

\section{Sample selection}

This study used all firms listed in Bursa Malaysia. Financial distress firms were selected based on Bursa Malaysia definition of PN4, PN 17 and Amended PN 17 from year 2000 to 2018 to represent financial distress firm sample for this study. Firms that do not fall under financial distress category were used to represent non-financial distress firm. This study followed the approach used by Sori, Hamid, Nassir and Mohamad (2001) by using all firms in order to obtain financial distress prediction model that could represent prediction model for Malaysian market and could be used for further analysis in the future. However, this study eliminated all financial firms from the sample due to the different in accounting practice used by those firms.

\section{Variables}

This study collected the financial information from firms' financial statement and annual report from 2000 to 2018 . The information was used to generate financial ratios such as liquidity ratio, activity ratio, profitability ratio and leverage ratio.

This study used liquidity ratio to represent ability of firms to meet their short term debt. The ratio was represented by current ratio and sales to working capital. As for activity ratio, this study use total asset turnover to represent the firm asset management ability in predicting financial distress. Another group of ratios used in this study was profitability ratio that represented by earnings before interest and tax to sales and net profit margin. Lastly, leverage ratio was represented by debt ratio, interest coverage ratio and shareholder's fund to total debt The selection of all ratios was similar to previous studies by Almansour (2015), Low et al. (2001), Platt and Platt (2008), Nair (2018). Lakshan and Wijekoon (2013), Altman (1997), Alifiah et al. (2013), Almansour (2015), Platt and Platt (2002), Parker et al. (2002), Kim and Upnej (2014), Yuniarti (2012), Abdullah et al. (2014), Abdullah and Ahmad (2005), and Jackson et al. (2018). All selected ratios are used to predict financial distress using the Logit Regression Model.

\section{Logit Regression Model}

This study used the Logic Regression Model (logit) in analysing collected data. The model generates the probability of financial distress to happen based on non-metric (categorical nominal) variable as dependent variable using coefficient of selected predictors (independent variables). Using the Logit Regression Model, dependent variable is basically the logarithm of 
the odds that the financial distress might happen. This study was basically based on the following model:

$\mathrm{Zi}=\alpha+\beta \mathrm{nX}+\mu$

Where

$\mathrm{Zi}=0$ for non-financial distress firms or 1 for financial distress firms

$\mathrm{X}=$ financial ratios for firms

$\mu=$ error term

Next, equation (1) will be re-write in logit regression functional form as follow:

$\ln \left(\frac{P}{1-P}\right)=\alpha+\beta_{\mathrm{n}} \mathrm{X}+\mu$

Thus, the probability of financial distress to occur generated based on following equation

$P=\frac{1}{1+e^{-\left(\alpha+\beta_{1} X_{1}+\beta_{2} X_{2}+\cdots+\beta_{n} X_{n}\right)}}$

Using equation (3), this study tried to identify the financial ratios as predictors that could differentiate between financial distress and financially healthy firms based on estimated maximum likelihood method. This study used stepwise procedure that exclude insignificant independent variables and only takes variables that are significant to be included into the model. This method is similar to Nam and Taehong (2000) and Md-Rus and Abdullah (2005). The financial ratios to be included into the prediction model must be statistically significant according to p-value generated by the model. In order to confirm the significance of the independent variables, this study also tested the variables' overall significance using likelihood ratio.

Lastly, this study used a confusion matrix approach to test the accuracy of the model. This approach tested the accuracy of the model based on the percentage of cases correctly predicted by the developed model. This approach predicts cases within the sample based on the developed model and the results obtained compared to the actual observations in the sample to generate the percentage of accuracy. The approach has been used by previous studies such as Ong, Yap, and Khong (2011) and Sori et al. (2001).

\section{Findings}

The result obtained from the Logit Regression analysis using stepwise procedure can be seen in Table 1. This table clearly shows that total assets turnover, earnings before interest and tax to sales, debt ratio, and shareholder's fund to total debt are significant predictors to predict financial distress.

Table 1: Result of Logit Regression Analysis (Stepwise Approach) For Firm Listed in Bursa Malaysia

\begin{tabular}{lllll}
\hline IV & $\boldsymbol{\beta}$ & Std. Error & $\mathbf{Z}$ & p-value \\
\hline Constant & -8.403 & 0.646 & -13.000 & $0.000 * * *$ \\
TATO & -0.588 & 0.143 & -4.110 & $0.000 * * *$ \\
EBITS & -0.558 & 0.171 & -3.265 & $0.001 * * *$ \\
DR & 11.424 & 0.983 & 11.620 & $0.000 * * *$
\end{tabular}


Volume 2 Issue 4 (September 2020) PP. 01-09

DOI 10.35631/AIJBAF.24001

\begin{tabular}{lrrr} 
SFTD 0.007 & 0.004 & 1.763 & $0.078 *$ \\
\hline Test & & & \\
Likelihood ratio test & & 443.476*** & \\
\hline
\end{tabular}

Note: TATO represent total asset turnover, EBITS represent earnings before interest and tax to sales, DR represent debt ratio and SFTD represent shareholder's fund to total debt. The star symbol (*) on p-value represent statistically significant at certain level; $* * *$ statistically significant at $1 \%$ level, $* *$ statistically significant at $5 \%$ level, and $*$ statistically significant at $10 \%$ level.

Table 2: Confusion Matrix

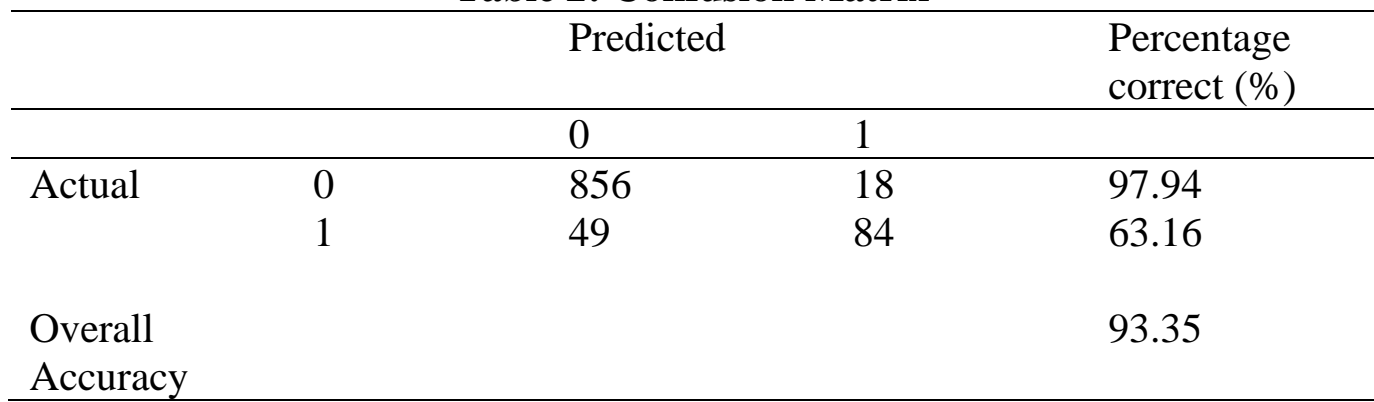

Total assets turnover was found to have negative coefficient and significant which is similar to previous studies by Altman (1968), Ong, Yap, and Khong (2011), Alifiah and Tahir (2018) and Almansour (2015). Ong et al. (2011) explained that probability of financial distress will reduce as total assets turnover increase due to firm ability to increase their sales that lead to increase in firm's cash flow and their ability to meet their obligation.

Another variable that was also found to be significant was earnings before interest and tax to sales which is similar to previous studies by Platt and Platt (2002) and Parker et al. (2002). Thus, as firm is able to generate high operating income, the probability of financial distress to occur will reduce. This is because firms with high operating income will have high ability to meet their financing cost and reduce the default risk and financial distress risk.

Based on Table 1, this indicates that debt ratio is positively significant to predict financial distress which the result is similar to previous studies by Abdullah et al. (2014), Lee and Yeh (2004), Sori et al. (2001) and Alifiah and Tahir (2018). Lee and Yeh (2004) explained that as firm increases its debt to finance their assets, the level of financial risk will also increase and the probability of firm to default will increase which could lead financial distress risk to become be greater.

The last variable that was found to be significant was shareholder's fund to total debt. The result showed that shareholder's fund to total debt had positive coefficient which indicates this variable is positively significant to predict financial distress. However, this result contradicted previous study like Abdullah and Ahmad (2005). This result might be due to the tax element that could lead to lower profit which lowers the firms' cash flow and their ability to meet financial obligation.

Lastly, Table 2 showed the model accuracy based on percentage that represents the accuracy level of this study model in predicting financial distress. The result showed that the model had the accuracy rate of $93.35 \%$ which is considered high. This indicates that the model could correctly predicted $93.35 \%$ out of all cases with the study sample. 


\section{Conclusion}

This study focuses on developing prediction model to predict financial distress for firms that are listed in Bursa Malaysia by using selected financial ratios as the predictors. The result showed that only total assets turnover, earnings before interest and tax to sales, debt ratio, and shareholder's fund to total debt displayed significant result to predict financial distress in Malaysian market. The developed model was able to predict most of the cases within the sample used which indicates that it has high accuracy. The result also showed that the model to predict financial distress for Malaysian market had different variables compared to the Zscore which is based on the Multiple Discriminant Analysis (MDA) model developed by Altman (1968).

Thus, this study suggests the inclusion of more predictors into the model and should also include other than financial ratios into the prediction model in the future studies. Predictors such as macroeconomic and corporate governance variables could be included into the model. Future studies could also include cash flow ratios in the model. All these variables could help to develop a better financial distress models for Bursa Malaysia listed firms.

\section{References}

Abdullah, N. A. H., \& Ahmad, A. H. (2005). Detecting financial distress. International Journal of Management Studies, 12(1), 77-95.

Abdullah, N. A. H., Zainudin, N., Ahmad, A., \& Md-Rus, R. (2014). Predictors of financially distressed small and medium-sized enterprises: A case of Malaysia. International Proceedings of Economics Development \& Research, 76(18), 108-111.

Abdullah, S. N. (2006). Board structure and ownership in Malaysia: The case of distressed listed companies. Corporate Governance, 6(5), 582-594.

Alifiah, M. N., Salamudin, N., \& Ahmad, I. (2013). Prediction of financial distress companies in the consumer products sector in Malaysia. Jurnal Teknologi, 64(1), 85-91.

Alifiah, M. N. \& Tahir, M. S. (2018). Predicting financial distress in the manufacturing and non-manufacturing sectors in Malaysia using macroeconomic variables. Management Science Letters, 8, 593-604.

Almansour, B. Y. (2015). Empirical model for predicting financial failure. American Journal of Economics, Finance and Management, 1(3), 113-124.

Altman, E. I. (1968). Financial ratios, discriminant analysis and the prediction of corporate bankruptcy. The Journal of Finance, 23(4), 589-609.

Altman, E. I., \& Narayanan, P. (1997): An international survey of business failure classification models. Financial Markets, Institutions and Instruments, 6(2), 1-57.

Beaver, W. H. (1966). Financial ratios as predictors of failure. Journal of Accounting Research 4(1), 71-111.

Bunn, P., and Redwood, V. (2003). Company-accounts-based modelling of business failures. Working paper, Bank of England Working Paper (210).

Dambolena, I. G., \& Khoury, S. J. (1980). Ratio stability and corporate failure. Journal of Finance, 35(4), 1017-1026.

Jackson, K. K., Bogonko, D. J., \& Kimutai, D. G. (2018). Effectiveness of accounting ratios in predicting financial distress of companies listed in Nairobi Securities Exchange. Business \& Management Journal, 1(1), 293-297. 
Khaliq, A., Altarturi, B. H., Thaker, H. M., Harun, M. Y., \& Nahar, N. (2014). Identifying financial distress firms: A case study of Malaysia's Government Linked Companies (GLC). International Journal of Economics, Finance and Management, 3(3), 141-150.

Kim, S. Y., \& Upneja, A. (2014). Predicting restaurant financial distress using decision tree and AdaBoosted decision tree models. Economic Modelling, 36(C), 354-362.

Laitinen, E. K. (1992). Prediction of failure of a newly founded firm. Journal of Business Venturing, 7(4), 323-340.

Lakshan, A. M., \& Wijekoon, W. M. (2013). The use of financial ratios in predicting corporate failure in Sri Lanka. Journal on Business Review, 2(4), 37-43.

Lee, T., \& Yeh, Y. (2004). Corporate governance and financial distress : Evidence from Taiwan. Corporate Governance, 12(3), 378-388.

Low, S. W., Nor, F. M., \& Yatim, P. (2001). Predicting corporate financial distress using the logit model: The case of Malaysia. Asian Academy of Management Journal, 6(1), 4961.

Md-Rus, R., \& Abdullah, N. A. H. (2005). Empirical investigation of failing companies in an emerging capital market. In 16th Asian Finance Association Conference, Malaysia.

Min, J. H. \& Lee, Y. C. (2008). A practical approach to credit scoring. Expert Systems with Applications, 35, 1762-1770.

Mohamed, S., Ang, J. \& Ahmadu, U. S. (2001). Predicting corporate failure in Malaysia: An application of the logit model to financial ratio analysis. Asian Academy of Management Journal, 6(1), 99-118.

Nair, J. (2018). A comparative analysis of working capital management in distressed and nondistressed companies in Indian steel sector. International Journal of Recent Scientific Research, 9(2), 24538-24542.

Nam, J. H., \& Taehong, J. (2000). Bankruptcy prediction: Evidence from Korean listed companies during IMF crisis. Journal of International Financial Management and Accounting, 11(3), 178-197.

Ong, S.-W., Yap, V. C., \& Khong, R. W. L. (2011). Corporate failure prediction: A study of public listed companies in Malaysia. Managerial Finance, 37(6), 553-564. https://doi.org/10.1108/03074351111134745

Parker, S., Peters, G., \& Turetsky, H. (2002). Corporate governance and corporate failure: A survival analysis. Journal of Corporate Governance, 2(2), 4-12.

Platt, H. D., \& Platt, M. B. (2002). Predicting corporate financial distress: Reflection on choicebased sample bias. Journal of economic and finance, 26(2), 184-199.

Platt, H. D., \& Platt, M. B. (2008). Financial distress comparison across three global regions. Journal of Risk and Financial Management, 129-162.

Reis, B. F. L (2019). Assessing financial distress through financial ratios. Published thesis, Instituto Superior de Contabilidade e Administração de Lisboa (ISCAL).

Restianti, T., \& Agustina, L. (2018). The effect of financial ratios on financial distress conditions in sub industrial sector company. Accounting Analysis Journal, 7(1), 25-33.

Scalzer, R. S., Rodrigues, A., Macedo, M. A. S. \& Wanke, P. (2018). Financial distress in electricity distributors from the perspective of Brazilian regulation. Energy Policy, 125, 250-259.

Sori, Z. M., Hamid, M. A. A, Nassir A. M., \& Mohamad Z. A. (2001). Forecasting corporate failure in Malaysian industrial sector firms. Asian Academy of Management Journal. 
Tinoco, M. H., \& Wilson, N. (2013). Financial distress and bankruptcy prediction among listed companies using accounting, market and macroeconomic variables. International Review of Financial Analysis, 30, 394-419.

Tuckman, H. P., \& Chang, C. F. (1991). Amethodology for measuring the financial vulnerability of charitable nonprofit organizations. Nonprofit and Voluntary Sector Quarterly, 20, 445-460.

Tuvadaratragool, S. (2013). The role of financial ratios in signalling financial distress: evidence from Thai listed companies. Published DBA thesis, DBA Southern Cross University, Lismore, NSW.

Yuniarti. (2012). Analysis of financial distress financial ratios basic and chemical company listed on the stock exchange. Journal of Economics, 6(2), 161-166. 